\title{
The Effect of Transformational Leadership, Work Discipline and Competence on Employee Performance PT. Ice Cream Campina Surabaya
}

\author{
Akbar Dwi Permana Putra', Bayu Airlangga Putra ${ }^{2}$ \\ University of Narotama \\ akbarpermana61.ap@gmail.com
}

\begin{abstract}
Abstrac.This study aims to determine the effect of Transfromational Leadership Style on, Work Discipline, and Competence on Employee Performance at PT. Campina Ice Cream Surabaya. This type of research uses a quantitative approach, where researchers distribute questionnaires as data retrieval media which are then processed into interval data which are then tested using the SPSS18 application. The population and samples in this study were 55 employees of PT. Campina Ice Cream Surabaya. The results of the simultaneous hypothesis test obtained $\mathrm{F}$ count value of 454,106 with a significant level of 0,000 , there is a simultaneous significant effect between transfromational leadership style, work discipline, and competence towards employee performance. In partial hypothesis testing, work discipline variables that do not significantly influence employee performance. While the results of the determination test obtained simultaneously (R square) of 0.964 means that the variation in the value of Employee Performance is influenced by the Style of Transformational Leadership, Work Discipline, and Competence of $96.4 \%$ while the remaining $3.6 \%$ is influenced by other variables not examined.

Keywords: Transfromational Leadership Style, Work Discipline, Competence, Performance employee.
\end{abstract}

\section{INTRODUCTION}

In a company many factors are involved and influence each other for the growth and development of a company. One of the things that is influential is the leadership factor. This factor is important because leadership is fundamental and must be a major concern in a company besides other factors. In the hands of leaders, various policies, decisions are made. Therefore it is not wrong if leadership gets the dominant portion in the company. What leadership can improve employee performance? To answer that question, there are many versions, but in general it can be said that leadership that is responsive, caring and sensitive to the problems of the company, especially the issue that embraces employees is a leadership model that can improve employee work.

This does not escape the important role of a leader who always provides: planning, motivation, procurement, direction of development, maintenance, dismissal and input from their employees. So that there will be reciprocity between the leader and his employees, or the symbiosis of mutualism so that good human resources are created effectively and efficiently. Theory of Transformational Leadership Style according to (Robins, 2006: 308) Transformational leaders pay attention to the things and development needs of each follower. In addition to the influence of leadership style, there are several things that make employee performance no better, namely work discipline and competency which will also trigger employee performance.

Along with leadership style theory, Discipline Theory According to Rivai (2011: 824) work discipline is a tool used by managers to communicate with employees so that they are willing to change behavior in an effort and increase one's awareness to comply with all applicable company rules and social norms. In the theory of competence, According to Mc Clelland (in Sudarmanto, 2015: 48), Competence is a basic personal characteristic which determines the success or failure of a person in doing a job or situation. In this case the company owner must pay attention to his employees, motivate to improve employee performance. Umam (2010: 189) defines performance as the work achieved by individuals in accordance with their roles or tasks in a certain period, which is related to the measurement of certain values or standards of the organization in which the individual works. 
The phenomenon that occurs in Campina companies is the leadership style that exists in PT. Campina Ice Cream is very good because it wants to make changes to the regulatory system better by changing the hours of work early so that it can motivate students to work. The company also provides guidance to employees to always comply with the regulations in the company. In terms of discipline, the company seeks to do an effective way by disciplining its employees so that they always arrive on time in work and not late. but the facts that occur in the field even though they have experienced changes by the company, there are still employees who are still working late and not on time, lack of employee screenings that are often late and not on time when working, these employees can be disrupted at work.

Table 1. Employee percentage data is late Employee Year (2018) until September

No month Percentage

\begin{tabular}{lll}
\hline 1. & Januari & $20 \%$ \\
\hline 2. & Februari & $22 \%$ \\
\hline 3. & Maret & $24 \%$ \\
\hline 4. & April & $25 \%$ \\
\hline 5 & Mei & $27 \%$ \\
\hline 6 & Juni & $28 \%$ \\
\hline 7 & Juli & $29 \%$ \\
\hline 8 & Agustus & $30 \%$ \\
\hline 9 & September & $31 \%$
\end{tabular}

Source: Processed by PT. Campina Ice Cream

They in the company become less than optimal. In terms of employee competency there has a standard value in working in the company, and the symptoms Employees in this company have 2 types of work, there are those who have broad skills, there are also employees whose skills are still standard. Employees who have extensive skills can get attention from the company and can get awards from the company and employees whose skills are still lacking even though they are not achievers, the company can still receive it. because the competence of employees in the company has different tendencies, the employees whose skills are still standard they always lose in terms of competency in the work so that they can influence their performance in the company. The purpose of this study is to determine the effect of partial and simultaneous transformational leadership style, work discipline and competence on employee performance.

\section{LITERATURE REVIEW}

\subsection{Transformational Leadership Style}

Yukl (2010: 305) that transformational leadership increases followers' motivation and performance more than transactional. With this leadership, according to Bass in Yukl (2010: 305) states that followers feel trust, admiration, loyalty and respect for leaders and they are motivated to do more than initially expected of them.

Transformational leadership style is a type of leader who inspires his followers to override their personal interests and have extraordinary influencing abilities. Robbins (2010: 472) states that, Transformational leadership is a leader who inspires followers to go beyond their personal interests that can bring profound and extraordinary impact to followers.

Transformational is the emphasis on the development of followers, therefore Yukl (2010: 316) suggests several indicators for transformational leaders, namely:

1) Vision and mission.

2) Explain a trusted vision.

3) Motivating towards the better.

4) Emphasizing values.

\subsection{Work Discipline}

According to Rivai (2010: 825), "Work discipline is a tool used by managers to communicate with employees so that they are willing to change behavior and as an effort to raise awareness of prevailing social norms. Discipline is the awareness and willingness of a person to comply with all applicable company regulations and social norms. (Malayu, 2007).

The indicators that affect employee work discipline (Dharma, 2003) are: 
1). Employee attendance

2) Accuracy of working hours

3) Wear work clothes and identification

4) Employee compliance with regulations.

\subsection{Competence}

Mc Clelland (in Sudarmanto, 2015: 48), Competence is a basic personal characteristic that becomes a determining factor for success or failure of someone in doing a job or situation. "" Different opinions on "State Civil Service Agency (in Mannulang, 2012: 201), defines competency as the capabilities and characteristics possessed by a civil servant in the form of knowledge, skills, and attitudes of behavior needed in carrying out his office duties, so that the Civil Servants can carry out their duties in a professional, effective, and efficient manner. And theory according to Spencer (in Palan, 2007: 6), suggests that competence refers to characteristics that underlie behavior that describes motives, personal characteristics (characteristics), self-concept, values, knowledge or expertise brought by someone who is of superior performance ( superior performer) at work.

In explaining the meaning of competence further and deeper, it is certainly not separated from the thoughts of a few names below.

According to Mangkunegara (2012: 196), the components of competence are related to knowledge, abilities and skills that directly affect their performance, which consists of:

1) Knowledge in a predetermined field.

2) Abilities that match their expertise

3) Skills

4) personal characteristics.

\subsection{Employee performance}

Employee performance according to Hasibuan (2012: 94) is a result of work achieved by someone in carrying out tasks assigned to him based on skills, experience, and sincerity as well as time. While performance or performance according to Moeheriono in Abdullah (2014: 3) is description of the level of achievement of an activity program or policy in realizing the organization's goals, objectives and mission as outlined through the strategic planning of an organization. A person's performance is said to be good if the individual's work results can go beyond the predetermined role or target.

Dimensions or performance indicators are aspects that measure the performance of:

John Miner (in Ruky, 2013: 11), suggests 5 dimensions that can be used as benchmarks in assessing performance, namely:
a. Quality.
b. Quantity.
c. Use of time in work, namely: absenteeism, delay, effective work time or lost working hours.
d. Cooperation.

\subsection{Research Concept Framework}

Based on the background of the problem, the problem formula, and the literature review that has been put forward, the conceptual framework of the research is described as follows: 


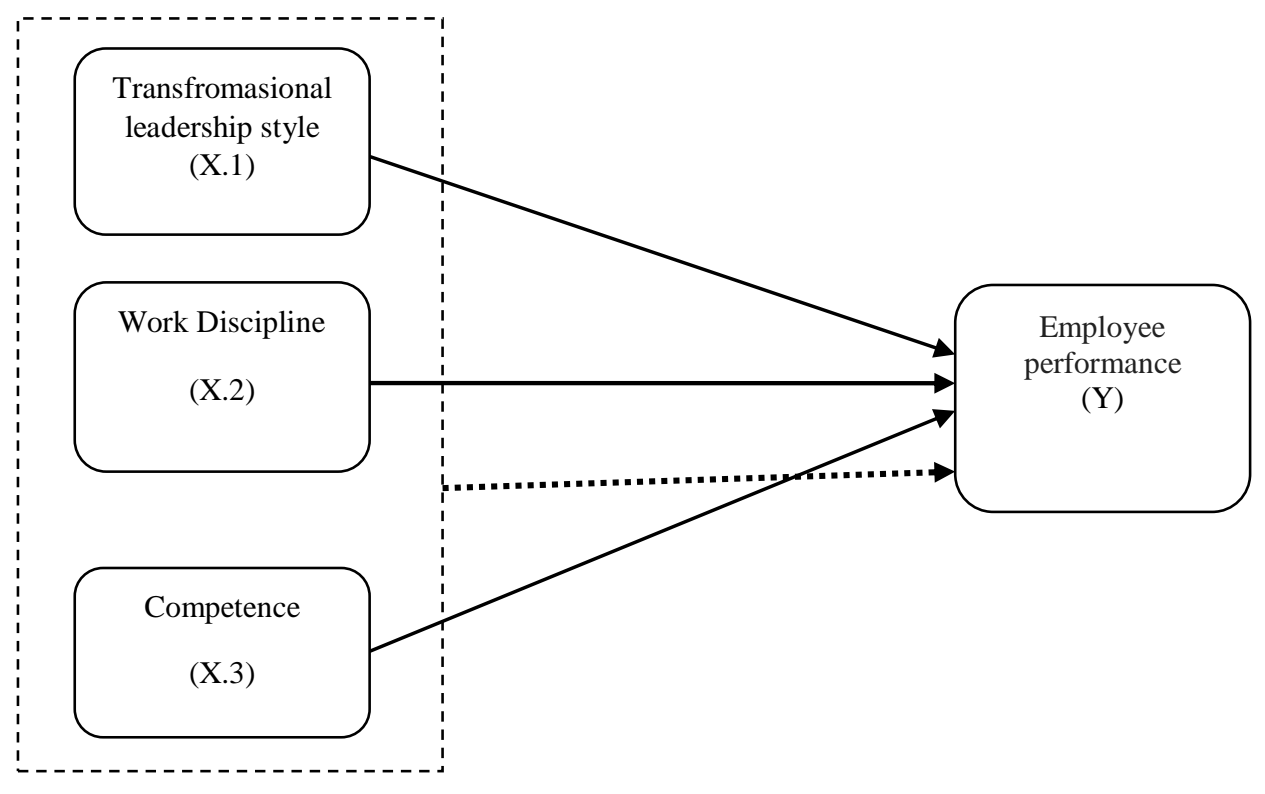

Figure 2.1: Research framework can be briefly explained as follows:

1. Partial

2. .......Simultaneous

It can be said that leadership has a significant effect on employee performance. Therefore in carrying out leadership must pay attention to various factors and make employees as partners in advancing the company.

Discipline is something that cannot be achieved in improving employee performance. Therefore, even though there is firmness in the leader, there must be awareness from the employee itself.

Competence is also very influential on employee performance. Therefore the task of the leader must know the competitiveness of skills among employees so that employees can work optimally.

\subsection{Hypothesis}

Following up on the background of the problems and problems presented and resting on a review of the theories described, this study takes the following hypothesis:

1. H1: There is a significant influence from the Transfromational Leadership Style, Work Discipline, and Competence partially on the performance of employees at PT. Campina Ice Cream Surabaya.

2. H2: There is a significant effect of the Transfromational Leadership Style, Work Discipline, and Competence simultaneously on the performance of employees at PT. Campina Ice Cream Surabaya.

\section{RESEARCH METHODS}

The type of research used is descriptive research with a quantitative approach with emphasis on testing the hypothesis in producing a conclusion The sample according to Sugiyono (2011: 81) is part of the number of characteristics possessed by the population. Given that there are not too many populations, all 55 members of the population are selected by census as a sample, thus the sampling technique used is the census technique, where all members of the population are used as samples.

\subsection{Research Variabels} Independent variables consist of:

a) Transfromational leadership style $\left(X_{1}\right)$ 
b) Discipline work $\left(\mathrm{X}_{2}\right)$

c) Competence $\left(\mathrm{X}_{3}\right)$

Dependent variable

employee performance (Y)

\subsection{Data analysis technique}

Data analysis is the process of simplifying data into a form that is easier to read and interpret in the process, often using statistics here to simplify very large amounts of research data into simpler and younger information understood. In this study used a quantitative approach and multiple linear regression analysis techniques. Quantitative research according to Sugiyono (2011: 8) can be interpreted as a research method used to examine certain populations or samples, sampling techniques are generally carried out in census, data collection uses research instruments using the SPSS application.

\section{RESULTS AND DISCUSSION}

\subsection{Reliability Test}

Reliability test is a measuring tool to measure a questionnaire which is an indicator of variables. Measurement of reliability is done by one shot or measurement once with the SPSS Cronbach Alpha (a) statistical test tool. a reliable variable if given the value of Cronbach Alpha> 0.60 (Nunnally in Ghozali, 2005). After testing the validity and eliminating a statement from an invalid indicator, a reliability test is carried out which produces the Cronbach alpha value as follows:

\subsection{Table reliablity test}

\begin{tabular}{|c|c|c|c|}
\hline Variable & $\begin{array}{c}\text { Cronbach } \\
\text { Alpha }\end{array}$ & $\begin{array}{c}\text { Koefisien } \\
\text { alpha }\end{array}$ & Status \\
\hline Transfromational Leadership Stylen (X1) & 0.789 & 0,600 & Reliabel \\
\hline Work Discipline (X2) & 0.744 & 0,600 & Reliabel \\
\hline Competence (X3) & 0.812 & 0,600 & Reliabel \\
\hline Employee performance (Y) & 0.732 & 0,600 & Reliabel \\
\hline
\end{tabular}

From the reliability test table the research variable above shows that all values of alpha croanbach from both dependent and independent variables are stated to be reliable or acceptable because they have values above 0.6 , which means that the statement from the research questionnaire is said to be reliable or reliable.

\subsection{Normal Distribution Test}

4.2 normal distribution test

One-Sample Kolmogorov-Smirnov Test

\begin{tabular}{|c|c|c|c|c|c|}
\hline & & $\begin{array}{c}\text { Transfromationa } \\
1 \text { Leadership } \\
\text { Style }\end{array}$ & $\begin{array}{c}\text { Work } \\
\text { Discipline }\end{array}$ & Competence & $\begin{array}{c}\text { Employee } \\
\text { performance }\end{array}$ \\
\hline \multicolumn{2}{|l|}{$\mathrm{N}$} & 55 & 55 & 55 & 55 \\
\hline \multirow[t]{2}{*}{ Normal Parameters ${ }^{\mathrm{a}}$} & Mean & 4.1045 & 4.0909 & 4.2409 & 4.2909 \\
\hline & Std. Deviation & .35254 & .38898 & .37566 & .37504 \\
\hline \multirow{3}{*}{$\begin{array}{l}\text { Most } \\
\text { Differences }\end{array}$} & Absolute & .238 & .189 & .182 & .202 \\
\hline & Positive & .176 & .120 & .136 & .161 \\
\hline & Negative & -.238 & -.189 & -.182 & -.202 \\
\hline \multicolumn{2}{|l|}{ Kolmogorov-Smirnov Z } & 1.765 & 1.405 & 1.353 & 1.500 \\
\hline \multicolumn{2}{|l|}{ Asymp. Sig. (2-tailed) } & .395 & .386 & .515 & .222 \\
\hline
\end{tabular}

From the table above it is known that the sig value of each variable is above 0.05 so that the variable is normally distributed 


\section{4,3 The summary test model table determines $R$ and $R 2$}

\begin{tabular}{|l|r|r|r|r|}
\hline \multicolumn{1}{|c|}{4.3 test model table determines R Square } \\
\hline Model & \multicolumn{1}{|c|}{$\mathrm{R}$} & \multicolumn{1}{c|}{ R Square } & Adjusted R Square & $\begin{array}{c}\text { Std. Error of the } \\
\text { Estimate }\end{array}$ \\
\hline 1 & $.982^{\mathrm{a}}$ & .964 & .962 & .07331 \\
\hline
\end{tabular}

b. Dependent Variable: Employee performance

Based on the results of the analysis of the summary model above, the R value of 0.982 means that the relationship between the independent variables Transformational Leadership Style, Work Discipline, and Competence with Employee Performance is tight and strong. This is indicated by the value of $\mathrm{R}$ approaching $100 \%$, which is $98.2 \%$. The simultaneous determination coefficient ( $\mathrm{R}$ square) of 0.964 means that the variation in the value of Employee Performance is influenced by the Style of Transformational Leadership, Work Discipline, and Competence of $96.4 \%$ while the remaining $3.6 \%$ is influenced by other variables not examined.

4.4 The influence of transformational leadership style, work discipline, and competence (partially) on the performance of employees.

In this study the conclusion is that transformational leadership style, work discipline, and competence partially influence the performance of employees of PT. Campina Ice Cream Surabaya. The leadership style variable has a partial effect on employee performance, this is in line with Robbins (2016) leadership is one of the driving forces that makes employees work according to the wishes of the institution or organization voluntarily and sincerely.

\begin{tabular}{|c|c|c|c|c|c|}
\hline \multicolumn{6}{|c|}{ Coefficients $^{\mathrm{a}}$} \\
\hline \multirow[t]{2}{*}{ Model } & \multicolumn{2}{|c|}{$\begin{array}{l}\text { Unstandardized } \\
\text { Coefficients }\end{array}$} & $\begin{array}{c}\text { Standardize } \\
d \\
\text { Coefficients }\end{array}$ & & \\
\hline & \begin{tabular}{l|l}
$\mathrm{B}$ \\
\end{tabular} & Std. Error & Beta & $\mathrm{t}$ & Sig. \\
\hline (Constant) & 0.068 & 0.121 & & 0.560 & 0.578 \\
\hline $\begin{array}{l}\text { Transfromational } \\
\text { Leadership Style }\end{array}$ & 0.229 & 0.054 & 0.215 & 4.264 & 0.000 \\
\hline Work Discipline & 0.180 & 0.047 & 0.187 & 3.858 & 0.000 \\
\hline Competence & 0.633 & 0.054 & 0.634 & 11.730 & 0.000 \\
\hline
\end{tabular}

a. Dependent Variable: Employee performance

The above equation means that if the transformational leadership style (X1) rises by one unit, then the performance of the employees of PT. Campina Ice Cream Surabaya (Y) will increase by 0.229 units assuming the other variables are constant. If the work discipline (X2) goes up one unit, then the performance of the employees of PT. Campina Ice Cream Surabaya (Y) will increase by 0.1180 units assuming the other variables are constant. If competence (X3) goes up one unit, then the performance of the employees of PT. Campina Ice Cream Surabaya (Y) will increase by 0.633 units assuming the other variables are constant. Furthermore, if the independent variables are considered non-existent, the performance of PT. Campina Ice Cream Surabaya is 0.068.

4.5 Effect of transformational leadership style, work discipline, and competence together (simultaneous) on employee performance.

ANOVA $^{b}$

\begin{tabular}{|c|c|c|c|c|c|c|}
\hline & Model & Sum of Squares & $\mathrm{df}$ & Mean Square & $\mathrm{F}$ & Sig. \\
\hline \multirow[t]{3}{*}{1} & Regression & 7.321 & 3 & \multirow{3}{*}{$\begin{array}{r}2.440 \\
.005\end{array}$} & \multirow[t]{3}{*}{454.106} & \multirow[t]{3}{*}{$.000^{\mathrm{a}}$} \\
\hline & Residual & .274 & 51 & & & \\
\hline & Total & 7.595 & 54 & & & \\
\hline
\end{tabular}


a. Predictors: (Constant), Competence, Work Discipline, Transfromational Leadership Style

b. Dependent Variable: employee performance

The findings in this study that all independent variables consisting of transformational leadership style, work discipline, and competence together (simultaneous) on the performance of employees of PT. Campina Ice Cream Surabaya. This finding is proven in the first hypothesis test using the F test. The calculation of multiple linear regression results in a calculated $F$ value of 454,106 with a significant level of 0,000 . This means that there are significant effects of transformational leadership style variables, work discipline, and competence together (simultaneously) on the performance of employees of PT. Campina Ice Cream Surabaya. The resulting multiple linear regression equation is $\mathrm{Y}=0.068+0.229 \mathrm{X} 1+0.180 \mathrm{X} 2+0.633 \mathrm{X} 3+\mathrm{e}$.

\subsection{Competency variables have dominant influence on the performance of employees.}

This study also produced findings that competencies had the most dominant influence on the performance of employees of PT. Campina Ice Cream Surabaya. Many factors influence employee performance, but employee competence as the spirit of an employee has an important role in carrying out the tasks assigned to employees. A performance must be preceded by capabilities and skills possessed, that is one of the driving forces for an employee to carry out the task. This is in line with the opinion of Keith Davis in his book Mangkunegara (2015: 113), one of the main factors affecting individual performance is the ability of individuals. Individual ability depends on the level of knowledge possessed, educational background, and mastered skills.

\section{CONCLUSIONS AND SUGGESTIONS}

\subsection{Conclusions}

The conclusions of this study are:

1. Transformational Leadership Style, Work discipline and competence simultaneously have a positive effect on the performance of employees of PT. Ice Cream Campina Surabaya.

2. Transformational leadership style, work discipline, and competence partially influence the performance of employees of PT. Campina Ice Cream Surabaya.

3. Work Discipline obtained a significant value of 0,000 (less than 0.05 ), meaning that the Working Discipline variable has no significant effect on employee performance (Y).

4. competence has a significant effect on the performance of employees of PT. Campina Ice Cream Surabaya.

\subsection{Suggestions}

Suggestions from this study are:

1. If the company wants to improve employee performance, the company should first improve employee work discipline as a top priority by doing a lot of things such as providing guidance so that it is not too late to work or raising awareness of responsibility for each employee's tasks, even though good leadership but the discipline of employees is less then it results in disharmony.

2. holding a meeting or gathering that aims to strengthen the relationship of human resources within the company so as to create a sense of kinship and create a harmonious work environment so that employees feel more comfortable and feel comfortable at work.

3. Whereas to improve competence, companies need to conduct training to improve skills, knowledge, self-concept, attitudes or behavior and motives for each employee.

\section{REFERENCE}

[1] Abdullah, M. Manajemen dan Evaluasi Kinerja Karyawan. Yogyakarta : Penerbit Aswaja Pressindo, 2014.

[2] Anwar and Mangkunegara, Manajemen Sumber Daya Manusia. Bandung: PT. Remaja Rosdakarya, 2012.

[3] Dharma and Agus, Manajemen Supervisi: Petunjuk Praktis Bagi Para Supervisor, Raja Grafindo Persada, Jakarta, 2003. 
[4] Hasibuan, Manajemen Sumber Daya Manusia (Edisi Revisi), Bumi Aksara, Jakarta, 2012.

[5] Malayu, Manajemen Sumber Daya Manusia. Jakarta: Bumi Aksara, 2007.

[6] Manullang and Marihot, Dasar-dasar manajemen, Gadjah Mada Unyversity Press, Yogyakarta, 2012.

[7] Palan, Competency Management. Teknik Mengimplementasikan Manajemen SDM berbasis Kompetensi untuk Meningkatkan Daya Saing Organisasi. Penerjemah: Octa Melia Jalal. Penerbit PPM. Jakarta, 2007.

[8] Rivai, Veithzal, Manajemen Sumber Daya Manusia untuk Perusahaan: dari Teori ke Praktik, Jakarta : RajaGrafindo Persada, 2011.

[9] Rivai, Veithzal and Sagala, Ella Jauvani, Manajemen Sumber Daya Manusia untuk Perusahaan andi Teori ke Praktik. Jakarta: PT Raja Grafindo, 2010.

[10] Ruky and Ahmad, Sistem Manajemen Kinerja, Gramedia Pusaka Utama, Jakarta, 2013.

[11] Robbins andTimothy, Perilaku Organisasi. Jakarta: Salemba Empat. Edisi ke 16, 2010

[12] Robbins, Stephen P, Perilaku Organisasi, PT Indeks, Kelompok Gramedia, Jakarta, 2006.

[13] Sudarmanto, Kinerja dan Pengembangan Kompetensi SDM. Yogyakarta: Pustaka Pelajar, 2015.

[14] Sugiyono, Metode Penelitian Kuantitatif Kualitatif and R\&D. Cetakan Ke-13. Penerbit Alfabeta. Bandung, 2011.

[15] Yukl and Gary, Leadership in Organization. Alih Bahasa oleh Udaya Jusuf:Kepemimpinan dalam Organisasi. Jakarta: Prehallindo, 2010. 